\title{
Application of geothermal energy and its environmental problems in Turkey
}

\author{
Alper Baba \\ Geothermal Energy Research and Application Center, \\ Izmir Institute of Technology, \\ Gulbahce, Urla, Izmir, Turkey \\ Email: alperbaba@iyte.edu.tr
}

\begin{abstract}
Human beings have been benefiting from geothermal energy for different uses since the dawn of the civilisation in many parts of the world. One of the earliest uses of geothermal energy was for heating and it was used extensively by Romans in Turkey. The Aegean region is favoured by a large number of thermal springs known since ancient times. However, it was first in the 20th century that geothermal energy was used on a large scale for direct use and electricity generation. The country's installed heat capacity is $2,705 \mathrm{MWt}$ for direct use and $322.39 \mathrm{MWe}$ for power production. In parallel to developing geothermal energy applications in Turkey, many sites are now experiencing problems such as water contamination associated with geothermal fluid. Especially, the high temperature solution of elements and compounds, causes operational limitations in geothermal power plants. These limitations are due to the severe scaling and corrosion of geothermal fluid.
\end{abstract}

Keywords: geothermal energy; balneology; environment; power generation; Turkey.

Reference to this paper should be made as follows: Baba, A. (2015) 'Application of geothermal energy and its environmental problems in Turkey', Int. J. Global Environmental Issues, Vol. 14, Nos. 3/4, pp.321-331.

Biographical notes: Alper Baba received his doctorate degree in the field of hydrogeology from the Dokuz Eylul University, Turkey. He has experience in hydrogeological and environmental geology problems in different parts of the world. He has been a Professor at Izmir Institute of Technology. He is teaching and conducting research in the field of groundwater, geothermal energy and hydrogeology. He has coordinated a variety of national and international R\&D projects in cooperation with research institutes and companies; among them NATO funded projects. He was awarded the Successful Young Scientists Award of Turkish Academy of Science and the Turkish Geological Engineering Association Gold Medal Award.

This paper is a revised and expanded version of a paper entitled 'Application of geothermal energy and its environmental problems in Turkey' presented at the IWA Regional Symposium on Water, Wastewater and Environment, Patras, Greece, 22-24 March 2014. 


\section{Brief historical review of geothermal energy in Anatolia and modern Turkey}

Turkey is favored by a large number of thermal springs known since classical and even prehistoric times. Especially, geothermal energy was used extensively for heating purposes in Anatolia since Romans era [Figures 1(a) to 1(f)]. Utilisation of the geothermal areas is mainly concentrated around several regions in Turkey. One of them is an ancient Roman city 'Hierapolis' (today Pamukkale) also called 'sacred city' founded in the 2nd century B.C. in which the ruins of it is the temples, theatres and baths have remained today. In this era, thermal water was used not only for bathing but also thanks to its unique quality the carpets were dyed in for assuring vividness of its colors for its lifetime. Today, Pamukkale (Hierapolis) is a popular tourist attraction and frequently visited for its travertine landscape and therapeutic advantages. About $5 \mathrm{~km}$ from Pamukkale, Karahayit settlement was located with its therapeutic benefits. This region is also rich in geothermal water sources, as well as thermomineral red iron muds. Perhaps, the most breathtaking sights in the hilly landscape of this area are the calciferous springs and cotton-colored terraces, and the dramatic view of the remains of the important Roman city of Hierapolis, founded by Eumenes II (King of Pergamon) in the 2nd century BC. Hierapolis reached its golden age in the 2nd and 3rd centuries, and became a famous city for its baths, fed by the hot nearby springs. Among several interesting monuments in the ruins of the antique city are the marble statues and architectural elements are preserved in one of the chambers of the old Roman Baths, called the Great Baths (Baba and Özbek, 2005).

Asclepieion in Pergamon is known for Hellenistic culture and architecture. Pergamon had its own 'sacral-healing centre' - Asclepieion, built as a place of worship and cult of Asclepios (a Greek god of medicine). A system of temples and other structures was built in the vicinity of radioactive geothermal springs. Interestingly, The Greek priests, physicists, and philosophers developed a school of healing in Pergamon, which can be called terraces formed by calcite precipitation from geothermal water. Special care was taken to rehabilitate the health in physical and spiritual aspects applying a combination of treatments such as treatment with hot waters and herbs being the most fundamental ones. Patients were treated with baths in geothermal waters, drinking of thermal waters, irrigations, massages, herbal therapies, diets, fasts, therapy through dreaming, autosuggestion, guided suggestion, and music. The Pergamon area is known for its geothermal springs even today. It can be seen many geothermal ruins in different parts of Turkey. 
Figure 1 Ruins of old spas in Turkey, (a) Hierapolis (photo from Kader Reyhan) (b) Allianoi (Hamamcioglu-Turan, 2013) (c) ruins of old spa in Gülbahce (Urla) (d) Ruins of an old spa in Denizli Region (e) geothermal field in Seferihisar Region (f) old spa from Aleksandrea Troia Region (see online version for colours)

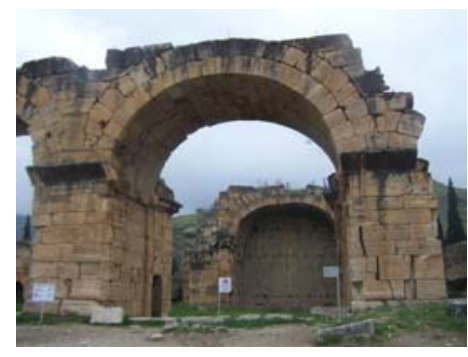

(a)

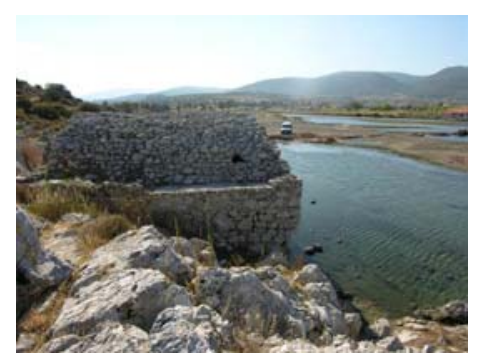

(c)

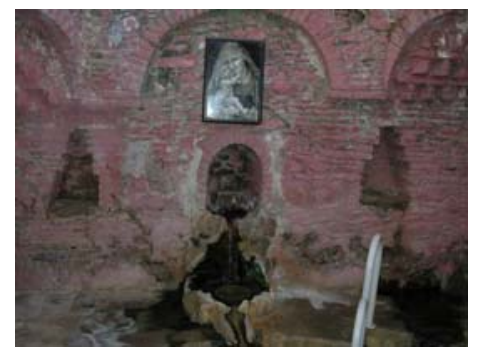

(e)

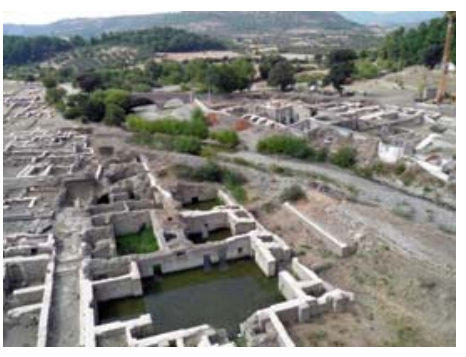

(b)

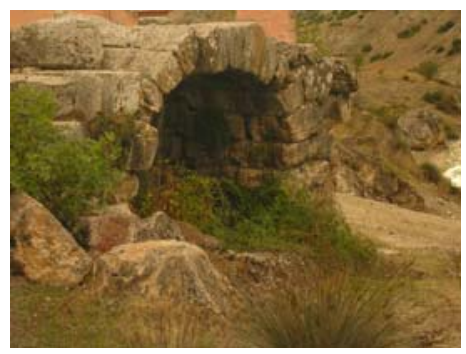

(d)

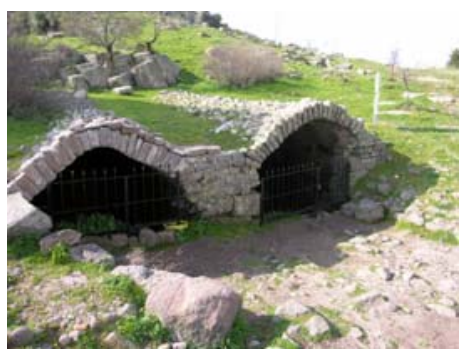

(f)

\subsection{Geothermal energy in Turkey}

Anatolia region is one of the most seismically active regions in the world, has a considerably high level of geothermal energy potential thanks to its geological and tectonic settings. Turkey is located within the Mediterranean Earthquake Belt, the complex deformation of which results from the continental collision between the African and Eurasian plates (Bozkurt, 2001). The border of these plates constitutes seismic belts marked by young volcanics and active faults with the latter allowing circulation of water and heat. The distribution of hot springs in Turkey roughly coincides with the distribution of the fault systems, young volcanism and hydrothermally altered areas (Simsek et al., 2002). Geothermal exploration studies in Turkey began in 1962 by the General Directorate of Mineral Research and Exploration (MTA): by the end of 2010, a total of 498 wells with total depth of 242,500 m had been drilled (Mutlu et al., 2014). There are a 
total of about 1,500 thermal and mineral water spring groups sped all over the country (Simsek et al., 2002; MTA, 1980; Simsek, 2009) (Figure 2). Most of these geothermal fluids have been seen in western Turkey. The highest $\left(287^{\circ} \mathrm{C}\right)$ bottom hole temperatures has been measured in western Turkey. The General Directorate of Mineral Research and Exploration of Turkey (MTA) did the first geothermal drilling studies in the region in 1963 in Balçova (İzmir). A district heating system with a total capacity of $2.2 \mathrm{MWt}$ began its operation in 1983 for heating offices, hospital, and dormitories of Dokuz Eylül University $\left(\sim 30,000 \mathrm{~m}^{2}\right)$. Furthermore, heating system for Turkey's largest indoor swimming pool, which has capacity of $1,600,000 \mathrm{kcal} / \mathrm{h}(\sim 6,694 \mathrm{MJ} / \mathrm{h})$, began operation with using the regional geothermal energy in February 1987 (Parlaktuna, 2014) [Figure 3(a)]. Many cities such as Afyon, Simav (Kutahya), Diyadin (Ağrı), and Salihli (Manisa) are currently using geothermal energy for space heating in the last ten years [Figures 3(b) to 3(d)]. In Turkey, geothermal energy is also used in various applications such as electricity generation, greenhouse and district heating, industrial processes, and balneology [Figures 3(b) to 3(d)]. Most of geothermal sites are low-medium enthalpy fields, which are suitable mostly for direct-use applications such as district heating, greenhouse heating, thermal facilities and balneology (Simsek, 2009; Baba and Ármannsson, 2006). The installed capacity is $2,705 \mathrm{MWt}$ for direct use (heating) and 322.39 MWe for power generation (Table 1). In addition, some geothermal power plants are under construction and some of them are in planning stage in western part of Turkey (Table 2).

Figure 2 Tectonic map of the eastern Mediterranean region showing structures developed from the Miocene to Holocene times and distribution of geothermal areas in Turkey (see online version for colours)

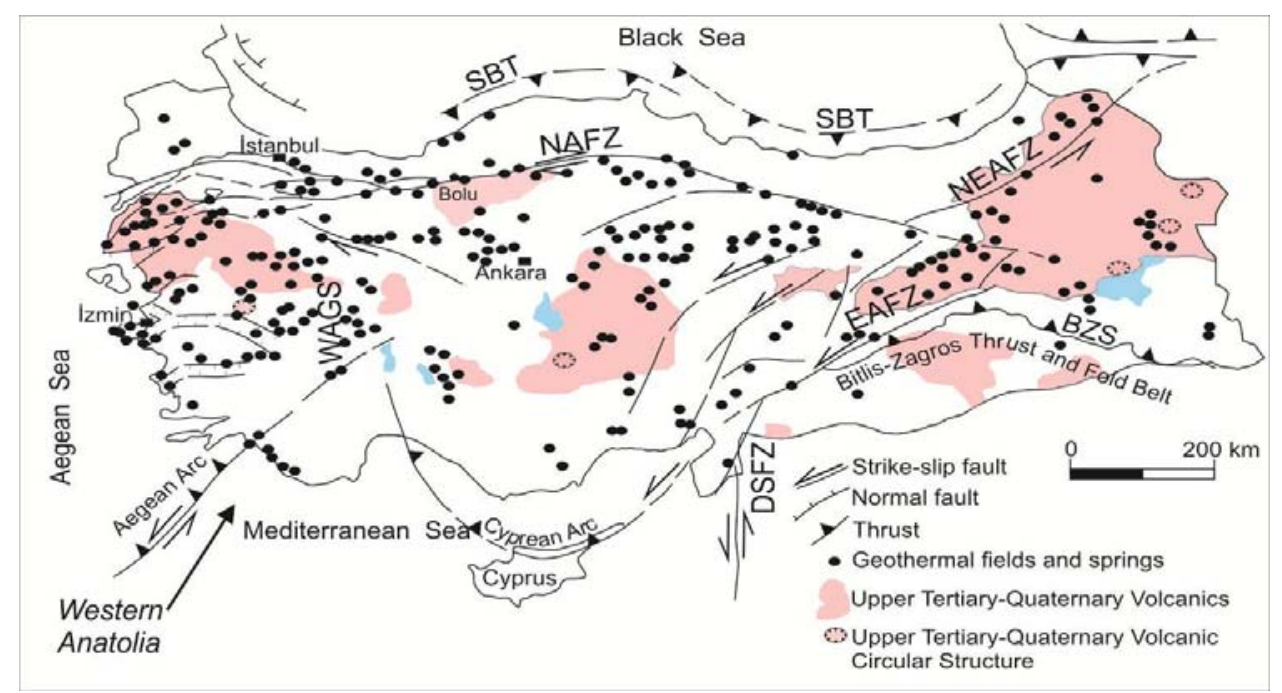

Notes: SBT, Southern Black Sea Thrust; NAFZ, North Anatolian Fault Zone; NEAFZ, Northeast Anatolian Fault Zone; EAFZ, Eastern Anatolian Fault Zone; WAGS, Western Anatolian Graben System; DSF, Dead Sea Fault Zone; BZS, Bitlis-Zagros Suture (Baba and Ármannsson, 2006).

Source: Simsek et al. (2002) and Yigitbas et al. (2004) 
Figure 3 Various applications of geothermal fluids in Turkey, (a) Swimming pool in Balçova İzmir (b) Greenhouses in Simav geothermal field (c) Geothermal power plant in Denizli (d) Balneotherapy in Denizli Basin (see online version for colours)

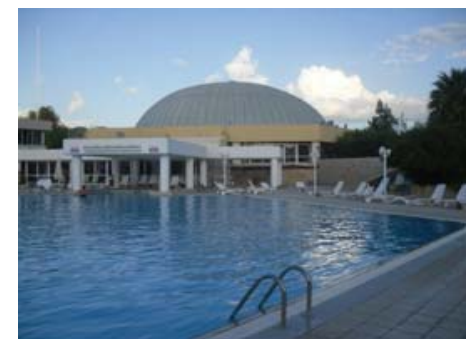

(a)

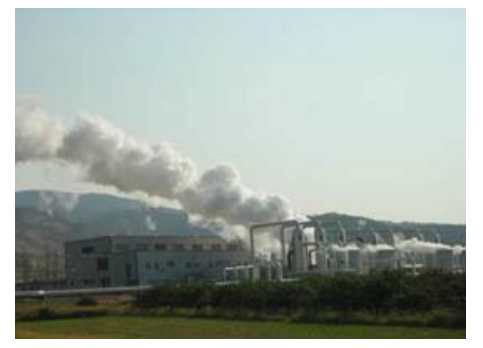

(c)

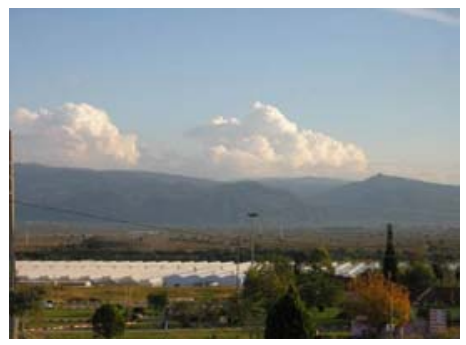

(b)

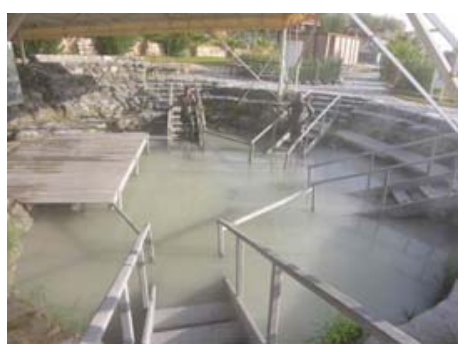

(d)

Table 1 Geothermal power plants of Turkey

\begin{tabular}{cccccc}
\hline Location & Power plant & $\begin{array}{c}\text { Startup } \\
\text { date }\end{array}$ & $\begin{array}{c}\text { Reservoir } \\
\text { temperature } \\
\left({ }^{\circ} \mathrm{C}\right)\end{array}$ & $\begin{array}{c}\text { Average reservoir } \\
\text { temperature }\left({ }^{\circ} \mathrm{C}\right)\end{array}$ & $\begin{array}{c}\text { Power } \\
\text { capacity } \\
(\mathrm{MWe})\end{array}$ \\
\hline Denizli & & & & \\
Kızıldere I & Zorlu - Kızıldere & 1984 & 242 & - & 17.4 \\
Kızıldere II & Zorlu - Kızıldere & 2013 & - & 145 & 80 \\
Sarayköy & Bereket & 2007 & - & 101 & 7.5 \\
Sarayköy & Jeoden & 2012 & & & 0.84 \\
Aydın/Sultanhisar & & & & 168 & \\
Salavatlı & Dora-1 & 2006 & 172 & 175 & 11.2 \\
Salavatlı & Dora-2 & 2010 & 176 & 170 & 17 \\
Salavatlı & Dora-3 & 2013 & - & & \\
Aydın/Germencik & & & & 220 & 47.4 \\
Ömerbeyli & Gurmat & 2009 & 232 & 170 & 20 \\
Hıdırbeyli & Irem & 2011 & 190 & 180 & 24 \\
Bozkoy & Sinem & 2012 & - & 180 & 24 \\
Bozkoy & Deniz & 2012 & - & 160 & 6.60 \\
Gümüşköy & Gümüşköy 1 & 2013 & 165 & 160 & 6.60 \\
Gümüşköy & Gümüşköy 2 & 2014 & 165 & &
\end{tabular}


Table 1 Geothermal power plants of Turkey (continued)

\begin{tabular}{lccccc}
\hline Location & Power plant & $\begin{array}{c}\text { Startup } \\
\text { date }\end{array}$ & $\begin{array}{c}\text { Reservoir } \\
\text { temperature } \\
\left({ }^{\circ} \mathrm{C}\right)\end{array}$ & $\begin{array}{c}\text { Average reservoir } \\
\text { temperature }\left({ }^{\circ} \mathrm{C}\right)\end{array}$ & $\begin{array}{c}\text { Power } \\
\text { capacity } \\
(\mathrm{MWe})\end{array}$ \\
\hline $\begin{array}{c}\text { Aydın/Kuyucak } \\
\text { Pamukören }\end{array}$ & Çelikler 1 & 2013 & & 170 & 22.50 \\
$\begin{array}{c}\text { Pamukören } \\
\text { Çanakkale }\end{array}$ & Çelikler 2 & 2013 & & 170 & 22.50 \\
$\quad$ Tuzla & Tuzla & 2010 & 174 & 160 & 7.5 \\
\hline Total & & & & & 322.39 \\
\hline
\end{tabular}

Table 2 Planned geothermal power plants of Turkey

\begin{tabular}{|c|c|c|c|}
\hline City/location & Field & Power plant & Planned capacity $(M W)$ \\
\hline \multirow[t]{7}{*}{ Manisa } & Merkez & Türkerler Sarıkız JES & 10.00 \\
\hline & Alaşehir & Enerjeo Kemaliye JES & 20.00 \\
\hline & Alaşehir & Türkerler Alaşehir JES & 24.00 \\
\hline & Alaşehir & Maspo JES-1 & 35.00 \\
\hline & Alaşehir & Maspo JES-2 & 35.00 \\
\hline & Alaşehir - Erenköy & Alaşehir JES & 30.00 \\
\hline & Salihli - Caferbeyli & Sanko JES & 15.00 \\
\hline \multirow[t]{2}{*}{ Denizli } & Sarayköy & Gök JES & 3.00 \\
\hline & Sarayköy - Tekke Hamam & Greeneco JES & 20.00 \\
\hline \multirow[t]{11}{*}{ Aydin } & Salavatlı & Dora-3b JES & 17.00 \\
\hline & Salavatli & Dora-4 JES & 17.00 \\
\hline & Sultanhisar & $\begin{array}{l}\text { Çelikler Sultanhisar } \\
\text { JES }\end{array}$ & 9.90 \\
\hline & Sultanhisar-Atça & Alres JES & 9.50 \\
\hline & Nazilli-Gedik & Kiper JES & 20.00 \\
\hline & Köşk - Umurlu & Karkey Umurlu JES & 12.00 \\
\hline & Germencik-Ömerbeyli & Efe JES & 162.5 \\
\hline & Germencik-Hıdırbeyli & Kerem JES & 24.00 \\
\hline & Y1lmazköy & Ken Kipaş JES & 24.00 \\
\hline & Kuyucak - Pamukören & $\begin{array}{l}\text { Çelikler Pamukören } \\
\text { JES-3 }\end{array}$ & 22.50 \\
\hline & Kuyucak - Pamukören & $\begin{array}{l}\text { Çelikler Pamukören } \\
\text { JES-4 }\end{array}$ & 22.50 \\
\hline Çanakkale & Ayvacık & Babadere JES & 3.00 \\
\hline \multirow[t]{2}{*}{ Bolu } & Seben & Bolu JES & 5.00 \\
\hline & & & 378.40 \\
\hline
\end{tabular}


Figure 4 Hydrogeochemistry of geothermal fluids in western Turkey (see online version for colours)

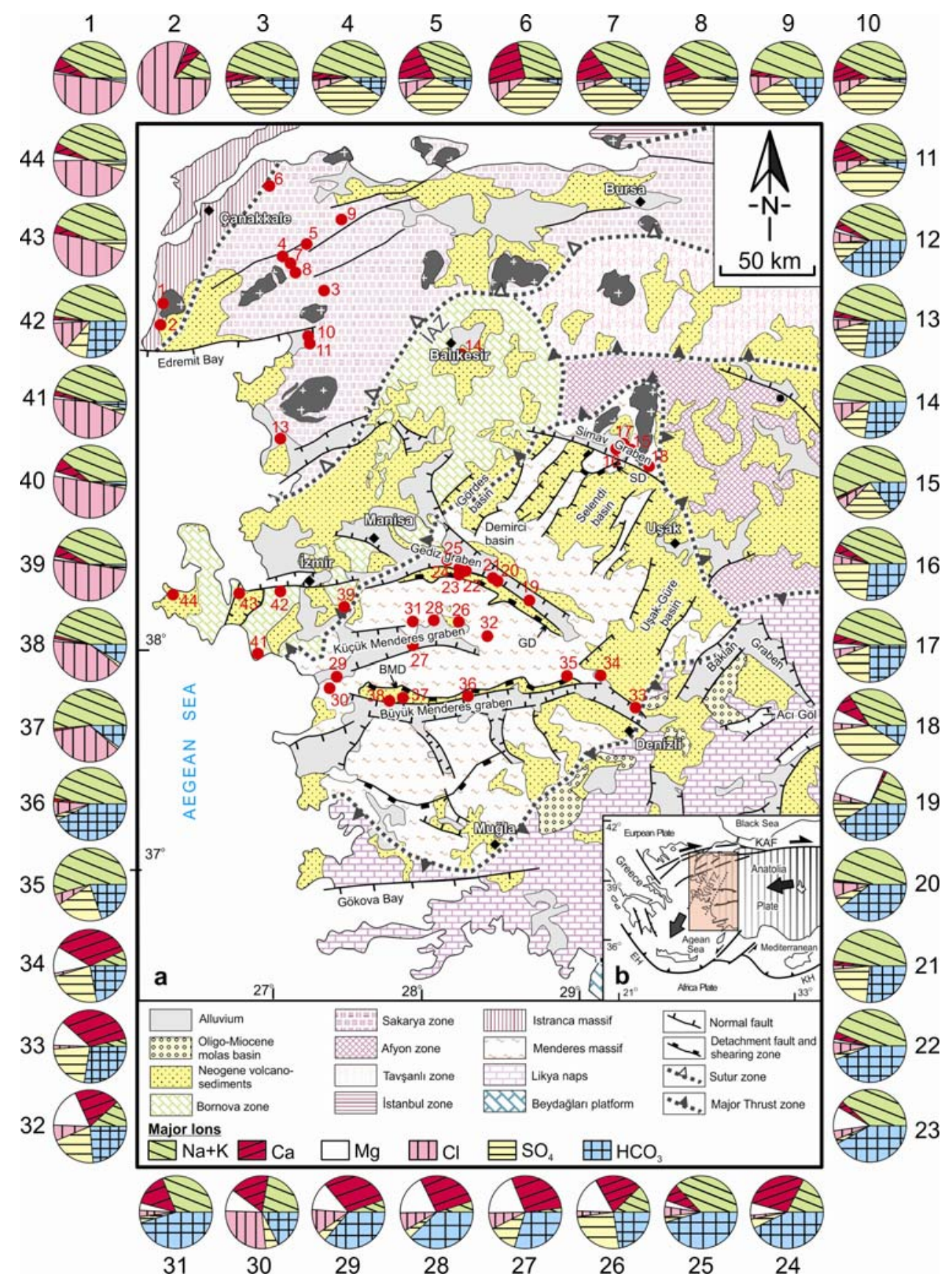

Source: Baba and Sözbilir (2012) 


\section{Hydrogeochemistry of geothermal system}

Generally, the chemical composition of each geothermal field is quite different from the others because of the complex lithology, tectonics and volcanic activity of Turkey (see Figure 4). For example, high temperature wells of Gümüşköy region are characterised by higher mineralisation with the predominant ions being $\mathrm{Na}^{+}, \mathrm{K}^{+}$and $\mathrm{Cl}^{-}$, and $\mathrm{HCO}_{3}^{-}$. On the other hand, the mineralisation of the 'low temperature' springs of Argavli and Sazlıköy is much lower and dominated by the presence of $\mathrm{Ca}^{2+}, \mathrm{Mg}^{2+}$, and $\mathrm{HCO}_{3}(\mathrm{Baba}$ and Sözbilir, 2012). The majority of thermal waters are of $\mathrm{Na}^{+}-\mathrm{Ca}^{2+}-\mathrm{HCO}_{3}=$ type in Turkey, although $\mathrm{Na}^{+}-\mathrm{Cl}^{-}$type waters characterise the coastal sites in western Anatolia reflecting sea water intrusion into the aquifers (Mutlu and Güleç, 1998; Baba and Sözbilir, 2012). The reservoir temperatures being assessed via the application of various geothermometers and/or measured in boreholes indicate that the western Anatolian province displays the highest geothermal potential in Turkey (Mutlu and Güleç, 1998). The $\mathrm{HCO}_{3}$ nature of most samples is attributed to the interaction between waters and carbonate reservoir rocks. This is also supported by the fact that Palaeozoic marbles, Mesozoic recrystallised limestones and Tertiary carbonate deposits comprise the reservoir rocks in most parts of Turkey (Mutlu et al., 2014; Mutlu and Güleç, 1998).

Geothermal fluids encountered in Turkey such as Tuzla (Çanakkale), Seferihisar (İzmir), Gülbahce (Urla) and Çesme (izmir) can be classified chemically as 95\% encrusting. These geothermal fluids are highly corrosive. In three of the 140 geothermal fields, the total dissolved solids (TDS) concentration in the geothermal fluid exceeds $5,000 \mathrm{ppm}$ and could cause serious utilisation problems and environmental impacts (Baba and Ármannsson, 2006; Gemici and Filiz, 2001; Mützenberg, 1997).

\section{Technical problems and environmental impacts from geothermal systems exploitation}

Geothermal energy is widely used for many applications such as power generation, district heating, chemical production, snow melting, fish production, industry and thermal tourism. However, geothermal brine can be extremely difficult to handle. Geothermal fluid display high contents of elements and gases. Therefore, they can severely affect the environment such as surface and groundwater in Turkey [Figure 5(a)]. In essence, with its high dissolved constituents and thermal content, geothermal fluid is known to have significant impacts on environment when disposed in an uncontrolled manner. In parallel to developing geothermal energy applications in Turkey, many sites are now experiencing impacts associated with not only waste geothermal fluid disposal but also uncontrolled surface eruptions during drilling operations [Figure 5(b)]. Also, serious environmental problems can arise during drilling phase. For example, a typical geothermal drill blew up and caused significant thermal and chemical contamination in Gediz gaben (western Turkey). The drilling site is surrounded by grape field damaged due to the explosions [Figure 5(b)]. The results show that uncontrolled geothermal fluid eruptions have been influenced groundwater resources of the area where water resources are commonly used for agricultural irrigation (Baba and Murathan, 2013). It has not been seen any significant effect at that time on groundwater resources of region. But concentration of some of heavy metals such as boron and lead have been increased in groundwater resources in this region. Additionally, the high temperature solution of 
elements and compounds causes operational limitations in geothermal power plants due to the severe scaling and corrosion of geothermal brine and steam [Figures 5(c) to 5(f)]. Different types of scales have been encountered in various geothermal areas in Turkey. For example, the major scaling species in geothermal brine typically include calcium, silica, and sulphide compounds. Particularly, in the western Turkey, mainly the formation of carbonate scaling can be observed. Calcite and aragonite are the main scaling compounds in the geothermal fields of Central Turkey. Saponite/hectorite like amorphous structure as main component, layered double hydroxide, and iron silicide are precipitated in geothermal systems of northwestern Turkey (Doğan et al., 2014; Baba et al., 2015).

Figure 5 Effect of geothermal fluid on exploitation system and the environment (see online version for colours)

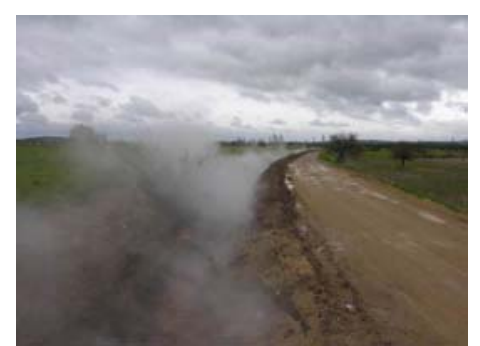

(a)

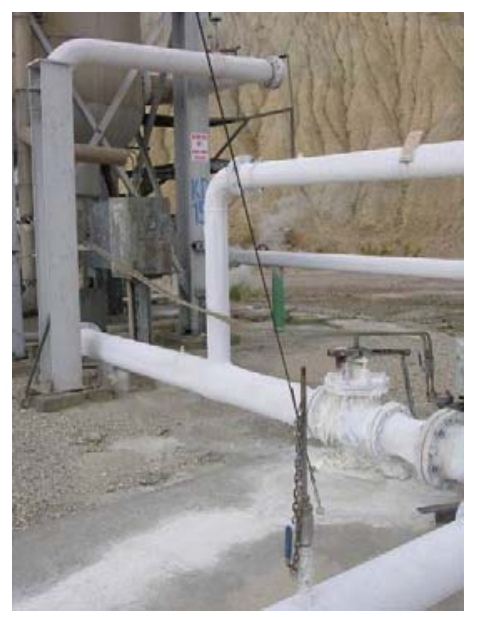

(c)

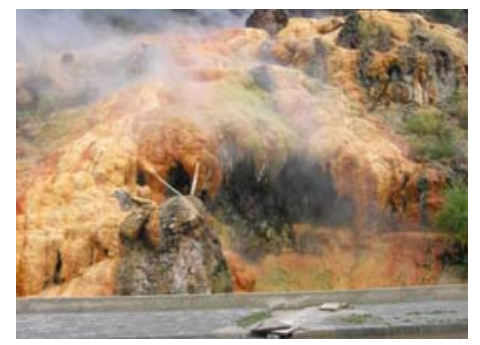

(e)

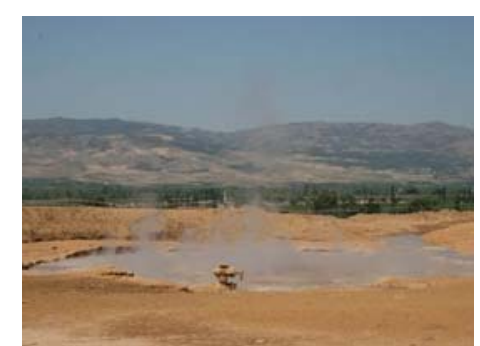

(b)

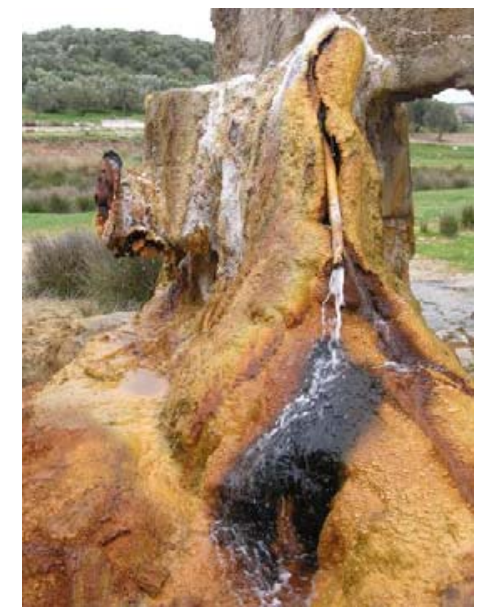

(d)

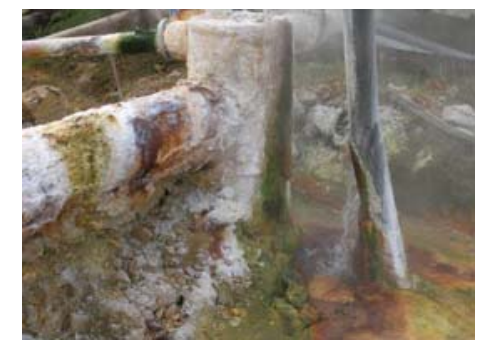

(f) 


\section{Conclusions}

Turkey has many thermal springs known since classical and even prehistoric times. Geothermal energy has been extensively used for heating since Roman times in Anatolia. Volcanic and tectonic activities have given rise to over 1,500 geothermal springs. Their importance has been recognised decades ago and the geothermal fluids have been utilised for district heating, industrial processing, domestic water supply, balneology and electric power generation. Installed heat capacity of Turkey is approximately 2,705 MWt for direct use and 322.39 MWe for power generation. The majority of thermal waters are of $\mathrm{Na}^{+}-\mathrm{Ca}^{2+}-\mathrm{HCO}_{3}=$ type, although $\mathrm{Na}^{+}-\mathrm{Cl}^{-}$type waters characterise the coastal sites in western Anatolia reflecting sea water intrusion into the aquifers. Geothermal brines contain high element and gas amounts and thus can be extremely difficult to handle in geothermal operations. Geothermal fluid includes high elevation elements and gases in Turkey. Furthermore, in parallel to developing geothermal energy applications in Turkey, many sites have been come across environmental problems such as surface and groundwater contamination. It is important to monitor impacts of geothermal systems on water resources and soil.

\section{Acknowledgements}

The author thanks the Dr. Ioannis K. Kalavrouziotis and reviewers for comment and suggestion.

\section{References}

Baba, A. and Ármannsson, H. (2006) 'Environmental impact of the utilization of a geothermal area in Turkey', Energy Source, Vol. 1, No. 3, pp.267-278.

Baba, A. and Murathan, A. (2013) 'Effect of geothermal fluid on groundwater quality in Gediz Graben, Western Turkey', ICWEE'2013, The 2nd International Conference on Water, Energy \& Environment, Kuşadas1, Turkey, 21-24 September, No. 272, pp.1-28.

Baba, A. and Özbek, O. (2005) 'Geothermal resources and its relation with human history: case study: Biga Peninsula’, Geoarchaeology - Archeogeophysics Symposium Proceeding, Y1ld1z Teknik University, Istanbul, 23-25 November, pp.65-66.

Baba, A. and Sözbilir, H. (2012) 'Source of arsenic based on geological and hydrogeochemical properties of geothermal systems in Western Turkey', Chemical Geology, Vol. 334, pp.364-377.

Baba, A., Demir, M.M., Koç, G.A. and Tuğcu, C. (2015) 'Hydrogeological properties of hypersaline geothermal brine and application of inhibiting siliceous scale via $\mathrm{pH}$ modification', Geothermics, Vol. 53, pp.406-412.

Bozkurt, E. (2001) 'Neotectonics of Turkey - a synthesis', Geodinamica Acta, Vol. 14, Nos. 1-3, pp.3-30.

Doğan, I., Demir, M. and Baba, A. (2014) 'Scaling problem of the geothermal system in Turkey', in Baba, A., Bundschuh, J. and Chandrasekharam, D. (Eds.): Geothermal Systems and Energy Resources: Turkey and Greece, pp.225-232, Series: Sustainable Energy Development 7, CRC Press.

Gemici, U. and Filiz, S. (2001) 'Hydrochemistry of the Cesme geothermal area, Turkey', Journal of Volcanology and Geothermal Research, Vol. 110, Nos. 2-4, pp.171-188. 
Hamamcioglu-Turan, M., Arisoy, Y., Nuhoglu, A. and Percin Erturan, Y. (2013) 'Protection of archaeological remains in the Yortanl1 Dam reservoir in Turkey', International Journal of Architectural Heritage, Vol. 7, No. 6, pp.653-672.

Mineral Research and Exploration (MTA) (1980) Hot and Mineral Water Inventory, General Directorate of Mineral Research and Exploration (MTA), MTA Rap., Ankara.

Mutlu H., Güleç, N. and Hilton, D.R. (2014) 'Chemical and isotopic constraints on the origin of thermal waters in Anatolia, Turkey: fluid-mineral equilibria approach', Baba, A., Bundschuh, J. and Chandrasekharam, D. (Eds.): Geothermal Systems and Energy Resources, CRC Press.

Mutlu, H. and Güleç, N. (1998) 'Geochemical characteristics of thermal waters from Anatolia (Turkey)', Journal of Volcanology and Geothermal Research, Vol. 85, pp.495-515.

Mützenberg, S. (1997) 'Nature and origin of the thermal springs in the Tuzla area, Western Anatolia, Turkey', in Schindler, C. and Pfister, M. (Eds.): The Marmara Poly-Project, pp.301-317, Vdf Hochschulverlag AG an der ETH, Zurich.

Parlaktuna, M. (2014) 'Balçova geothermal field district heating system: lessons learned from 16 years application', Baba, A., Bundschuh, J. and Chandrasekharam, D. (Eds.): Geothermal Systems and Energy Resources, CRC Press.

Simsek, S, Yildirim, N., Simsek, Z.N. and Karakus, H. (2002) 'Changes in geothermal resources at earthquake regions and their importance', Proceedings of Middle Anatolian Geothermal Energy and Environmental Symposium, pp.1-13.

Simsek, S., (2009) 'Geothermal energy development possibilities in Turkey', NUMOW Conference on 'Geothermal Energy in Turkey', Potsdam-Germany, 1 October, pp.1-6.

Yigitbas, E., Elmas, A., Sefunc, A. and Ozer, N. (2004) 'Major neotectonic features of eastern Marmara region, Turkey: development of the Adapazari-Karasu corridor and its tectonic significance', Geological J., Vol. 39, No. 2, pp.179-198. 